\title{
Gaya Kepemimpinan, Kohesivitas Kelompok, Dan Komitmen Pada Partai Politik
}

\author{
Yos Budiharto \\ Koentjoro \\ Universitas Gadjah Mada
}

\begin{abstract}
Organizational commitment has been conceptualised and measured in various ways. The current study was conducted to test aspects of three component model of organizational commitment which integrates the various concepts. The three component of organizational commitment in this study are affective, continuance and normative commitment. The proposed independent variables are transformational leadership, transactional leadership and group cohesiveness which were assumed to have significant relationship with organizational commitment. The data of this study were collected through questionnaires carried out to 120 cadres who were active in one political party, considered as nationalist - and secular party, in Yogyakarta. The study revealed that the three independent variables are empirically undifferentiated to the three components model of organizational commitment. Specifically, this study found that transformational leadership, transactional leadership, group cohesiveness, age and length of cadre membership are positively and significantly related to continuance commitment. When tested individually, it shows that age does not have positive relationship with the three component model of commitment.
\end{abstract}

\section{Key Words : Leadership Styles, Group Cohesiveness Commitment}

\section{Pendahuluan}

$\mathrm{D}$ inamika keberadaan partai politik di In donesia diramaikan oleh banyaknya anggota kader partai atau pengurus dari partai politik yang keluar masuk dari satu partai politik ke partai politik yang lainnnya atau bahkan keluar dari partai politik tertentu untuk kemudian mendirikan partai politik baru lagi. Berbagai kasus yang menyangkut hal tersebut di atas banyak dimuat dalam media massa. Sebagai contoh, beberapa kader Partai Demokrasi Indonesia Perjuangan seperti Dimyati Hartono, Eros Djarot dan Giri Mulyono keluar dari partai politik, kemudian mendirikan partai politik baru. Berbagai alasan telah dilontarkan sebagai alasan keluarnya mereka dari partai (Anita, 2002). Permasalahan yang dialami PDI Perjuangan sangat menarik untuk dikaji berdasarkan sudut pandang psikologi.

Dari kilasan di atas penulis mencermati adanya tiga variabel utama yang dapat dikaji secara psikologis. Kajian pertama berkaitan dengan komitmen terhadap organisasi, apapun bentuknya termasuk organisasi partai politik. Komitmen, menurut Hornby (1987), ialah suatu bentuk perjanjian yang harus dipenuhi oleh orang yang bersangkutan. Dari kasus berdirinya partai-partai politik baru oleh para mantan kader partai PDI Perjuangan 
dapat menandakan rendahnya komitmen terhadap partai. Namun demikian, kita tidak begitu saja menarik kesimpulan sedemikian mudahnya. Hal ini dikarenakan adanya faktorfaktor lain yang mempengaruhi tingkat komitmen anggota terhadap organisasi politiknya tersebut.

Kajian kedua, berkaitan dengan kohesivitas kelompok dalam partai. Hampir sudah menjadi rahasia umum bahwa konflik telah melanda tubuh PDI Perjuangan. Konflik kepentingan (conflict of interest), konflik horizontal, dan konflik vertikal semuanya merupakan tipe konflik antar pribadi. Banyaknya kader yang keluar dari tubuh partai ini menunjukkan bahwa konflik tersebut telah mengeskalasi ke arah konflik destruktif. $\mathrm{Hal}$ yang tidak dapat dielakkan dari suatu konflik adalah berkenaan dengan arahnya yang bisa merusak (destructive) atau produktif (productive). Aspek destruktif di antaranya adalah kecurigaan, muslihat, seranga fisik, dan pemutusan hubungan, sedangkan aspek produktif pada umumnya tidaklah begitu jelas (Keashly, 1997). Adanya konflik yang terjadi dalam tubuh partai berlambang banteng ini menunjukkan bahwa kohesivitas kelompok dalam partai sangat rendah. Johnson (2000) menyatakan bahwa dalam kelompok yang sangat tinggi kohesivitasnya saling ketergantungan antara satu anggota dengan anggota yang lain saling percaya, saling mengerti dan merasa aman di dalam kelompok, sangat tinggi. Kuatnya ikatan antara masing-masing anggota menjadikan kelompok mempunyai hanya satu tujuan yang sesungguhnya merupakan integrasi dari tujuan-tujuan dan nilai-nilai dari para anggota kelompok. Apabila kohesivitas kelompok pada partai PDI Perjuangan tinggi, kecil kemungkinan tereskalasinya suatu konflik menjadi destruktif yang menyebabkan seseorang mengambil jalan pintas keluar dari partai, melupakan komitmen yang telah disetujui bersama dahulu.

Kajian ketiga, berkenaan dengan leadership. Seperti telah diungkapkan oleh Haris, pengamat politik dari LIPI, dalam liputan yang dilakukan Ismail (2002) dalam situs tempointeraktif.com, bahwa kepemimpinan Megawati cenderung ke arah otoriter. Kepemimpinan otoriter biasanya mempertahankan wewenangnya dengan cara memerintah dan memberitahu pengikutnya apa yang harus dikerjakan tanpa melakukan konsultasi terlebih dahulu (DuBrin, dkk., 1996). Pada jaman organisasi yang modern seperti sekarang ini, kepemimpinan otoriter biasanya tidak akan bertahan lama karena mengundang ke-tidakpuasan anggota organisasi tersebut (Daft, 1999). Terlebih dalam dunia politik, dinamikanya selalu berubah. Seorang pemimpin tidak dapat menghentikan perubahan yang terjadi di dalam maupun di luar organisasi yang dipimpinnya dalam rangka untuk memenangkan persaingan. Pemimpin saat ini masih haruslah memiliki ketrampilan yang adaptif dengan perubahan-perubahan di dalam ataupun di luar organisasi yang dipimpinnya. Tannenbaum dan Schmidt dalam Daft (1999) menyatakan bahwa gaya kepemimpinan seorang pemimpin harus mengikuti keadaan lingkungan organisasi. Organisasi yang dapat bertahan baik dalam perubahan-perubahan yang demikian cepatnya ini harus memiliki pemimpin yang dapat membuat perubahan internal menjadi seimbang dengan perubahan di luar organisasinya. Welch, CEO dari General Electric menyatakan bahwa apabila perubahan yang terjadi di luar organisasi kita lebih cepat atau tidak dapat diikuti kecepatan perubahan di dalam organisasi kita maka akhir dari organisasi sudah sangat dekat (Daft, 1999)

Salah satu gaya kepemimpinan yang memiliki dampak substansial dan dapat memperbaharui organisasi ialah ke-pemimpinan transformasional. Kepemimpinan transformasional memiliki kemampuan untuk membawa perubahan-perubahan dalam visi, strategi dan budaya organisasi. Sementara itu kepemimpinan transaksional lebih mengacu kepada keadaan saat ini dan memaksimalkan 
organisasi untuk tetap efisien seperti saat ini. Pemimpin transaksional cenderung mempertahankan kestabilan dalam organisasi daripada memperomosikan perubahan. Dalam kehidupan berpolitik kedua gaya kepemimpinan tersebut dapat saja diterapkan dalam memimpin partai politik namun tentunya harus dilihat kepemimpinan seperti apakah yang lebih efektif di mata pengikutnya. Kepemimpinan yang tidak efektif dan tidak berpihak pada anggota atau bawahannya tentunya akan menyebabkan mereka melupakan komitmen terhadap tugas-tugas partainya.

\section{Permasalahan}

Berdasarkan latar belakang per-masalahan di atas, maka penulis merumuskan masalah penelitian sebagai berikut :

1. Apakah persepsi anggota kader partai terhadap gaya kepemimpin transformasional dan transaksional serta kohesivitas kelompok dalam partai berhubungan dengan komitmen mereka terhadap partai?

2. Apakah usia anggota kader dan lama menjadi anggota kader dalam partai berhubungan dengan komitmen terhadap partai?

\section{Hipotesis}

Berdasarkan perumusan permasalahan di atas maka hipotesis penelitian ini ialah : "Gaya kepemimpinan transformasional dan transaksional, kohesivitas kelompok dalam partai, lama menjadi anggota kader dalam partai, dan usia berhubungan positif dengan komitmen terhadap partai".

\section{Dasar Teori}

Komitmen. Secara historis, menurut Becker dan Billings (dalam Greenberg dan
Baron, 1997) ada dua pendekatan yang digunakan untuk menjelaskan dasar pembentukan komitmen yaitu side orientation dan goal congruence orientation.

a. Side-bets orientation. Orientasi ini memiliki fokus pada persepsi terhadap kumpulan investasi yang aka hilang apabila meninggalkan organisasi tersebut. Pendapat ini menyatakan bahwa meninggalkan organisasi akan lebih banyak merugikan karena orang takut akan kehilangan apa yang telah diinvestasikan pada organisasinya selama ini dan juga merasakan bahwa mereka belum tentu akan memperoleh gantinya.

b. Goal-congruence orientation. Orientasi ini berfokus pada sejauh mana seseorang dalam organisasi melihat adanya kesesuaian antara tujuan pribadi dan tujuan organisasi. Pendekatan ini merefleksikan keinginan orang untuk menerima dan mencapai tujuan organisasi. Orientasi ini juga memandang komitmen organisasi sebagai suatu hasil dari 3 faktor yaitu : (1) penerimaan terhadap nilainilai dan tujuan organisasi, (2) keinginan untuk menolong organisasi dalam pencapaian tujuannya, dan (3) keinginan untuk menetap dalam organisasi.

Steven, dkk (Steers, 1985) melihat komitmen melalui dua pendekatan, yaitu : pendekatan pertukaran (exchange approach) dan pendekatan psikologis ( $p$ sychological approach). Pendekatan pertama lebih menekankan kepada apa yang diperoleh oleh karyawan dari organisasi tempat ia bekerja. Semakin besar apa yang diperoleh oleh karyawan dari organisasi tempat ia bekerja, maka komitmen yang ditunjukkan oleh karyawan juga semakin besar. Pendekatan psikologis lebih menekankan pada pandangan karyawan terhadap organisasi tempat ia bekerja. Hal ini berarti semakin positif karyawan memandang organisasinya, maka akan memberikan tingkat komitmen lebih tinggi terhadap organisasi tersebut. Meyer dan Allen (1990) mengembangkan konsep tentang komitmen yang mencerminkan pendekatan 
dari Becker (1996) ke dalam tiga tema umum, yaitu affective attachment, perceived cost dan obligation. Menurut pandangan yang mendasarkan pada affective attachment, komitmen organisasi dirumuskan sebagai keterikatan emosional atau afektif terhadap organisasi sedemikian rupa sehingga karyawan mengidentifikasikan diri terlibat dan menikmati keanggotannya di dalam organisasi. Menurut pandangan berdasarkan perceived cost, komitmen dia pandang sebagai suatu kecenderungan untuk terlibat secara konsisten dalam rangkaian kegiatan berdasakan pengenalan individu terhadap kerugian yang akan dipikul jika menghentikan kegiatan. Obligation, memandang kmt sebagai suatu keyakinan yang berkaitan dengan tanggung jawab seseorang terhadap organisasinya.

Berdasarkan tiga tema umum tersebut, Meyer dan Allen (1990) menyusun komitmen organisasi ke dalam tiga dimensi yang diberi komitmen afeksi (affectve commitment), komitmen menerus (continuence commitment) dan komitmen normatif (normative commitment). Komitmen afeksi (affective commitment) merupakan kekuatan keinginan seseorang untuk tetap meneruskan bekerja bagi organisasi karena ia merasa cocok dengan organisasi tersebut dan memang ingin melakukannya. Komitmen menerus (continuence commitment) merupakan kekuatan keinginan seseorang dalam organisasi untuk terus bekerja bagi organisasi karena ia membutuhkannya dan tidak mampu untuk melakukan hal lainnya lagi. Setelah kedua komponen tersebut diteliti, para ahli menemukan komitmen baru yaitu komitmen normatif. Komitmen normatif mengacu kepada perasaan akan keharusan anggota organisasi untuk menetap dalam organisasi karena adanya tekanan dari luar individu misalnya nilai sosial. Tiga model komitmen Meyer dan Allen (1990) kemudian digunakan dalam penelitian ini.

Gaya kepemimpin trans-formasional dan transaksional. Awalnya, konsep gaya kepemimpin transformasional dan transaksional difomulasikan oleh Burns (1978) melalui penelitian deskriptif pada para pemimpin politik. Bass, ditahun 1985 mulai mengembangkan ide dasar gaya kepemimpin transformasional dan transaksional dari Burn (1978). Masih dengan pengertian yang hampir serupa, Bass memandang gaya kepemimpin transaksional sebagai pertukaran imbalan (reward) atas kepatuhan bawahan. Sementara itu, gaya kepemimpin transformasional dijelaskan berdasarkan dampak yang dihasilkan oleh perilaku pemimpin terhadap bawahannya: kesetiaan, rasa percaya, penghormatan terhadap pemimpin dan termotivasi untuk melakukan hal yang jauh lebih baik daripada apa yang diharapkan. Menurut Bass (1985), pemimpin transformasional mengubah dan memotivasi bawahannya melalui cara : (1) menyadarkan bawahan betapa pentingnya hasil dari tugas yang diemban, (2) mengarahkan mereka akan betapa pentingnya untuk mendahulukan kepentingan organisasi atau kelompok daripada kepentingan pribadi, dan (3) mengaktifkan kebutuhan pada level yang lebih tinggi. Formulasi awal perilaku transformasional Bass (1985) hanya mencakup tiga perilaku yaitu : karisma, perhatian individual dan stimulasi intelektual. Revisi teori tersebut akhirnya menambah satu lagi perilaku transformasional yaitu motivasi inspirasional (Bass dan Avolio, 1990). Sementara itu konsep gaya kepemimpin transaksional pada awalnya mencakup dua perilaku transaksional yaitu : imbalan kontingensi (contingency reward) dan manajemen pasif dengan pengecualian (passive management by exception). Revisi terhadap teori transaksional tersebut menambahkan dua perilaku lagi yang mencakup manajemen aktif dan kepemimpinan laissezfaire. Perilaku kepemimpinan transformasional dan transaksional secara ringkas pada tabel 1 : 
Tabel 1

Aspek kepemimpinan transformasional

\begin{tabular}{|c|c|}
\hline Aspek & Perilaku kepemimpinan transformasional \\
\hline Karismatik & $\begin{array}{l}\text { Memberi visi dan misi, menumbuhkan rasa bangga } \\
\text { anggota, mampu memperoleh kepercayaan dan } \\
\text { respect dari bawahan. }\end{array}$ \\
\hline Inspirasional & $\begin{array}{l}\text { Mengkomunikasikan harapan yang tinggi, } \\
\text { menggunakan simbol untuk memfokuskan usaha } \\
\text { bawahan, menyatakan tujuan penting secara } \\
\text { sederhana dan mudah dimengerti }\end{array}$ \\
\hline Stimulasi Intelektual & $\begin{array}{l}\text { Meningkatkan kecerdasan, rasionalitas dan } \\
\text { pemecahan masalah yang cermat dari bawahan }\end{array}$ \\
\hline Perhatian Individual & $\begin{array}{l}\text { Memberi perhatian secara pribadi, memperlakukan } \\
\text { setiap bawahan secara pribadi, memberikan } \\
\text { bimbingan dan saran. }\end{array}$ \\
\hline Aspek & Perilaku kepemimpinan transaksional \\
\hline Imbalan Kontingensi & $\begin{array}{l}\text { Menukar penghargaan atas usaha bawahan, } \\
\text { menjanjikan penghargaan untuk kinerja yang baik, } \\
\text { menghargai prestasi }\end{array}$ \\
\hline Manajemen dengan Eksepsi ( aktif̂́) & $\begin{array}{l}\text { Mengamati \& mencari penyimpangan kinerja sesuai } \\
\text { aturan \& standar kinerja yang ditentukan, ambil } \\
\text { tindakan korektif. }\end{array}$ \\
\hline Manajemen dengan Eksepsi (pasif) & $\begin{array}{l}\text { Melakukan intervensi ketika standar kine rja tidak } \\
\text { tercapai }\end{array}$ \\
\hline
\end{tabular}

(Sumber : Bass, dalam Steers dkk., 1996:630) 
Kohesivitas kelompok. Berbagai ahli telah mencoba untuk mendefinisikan kohesivitas kelompokdalam kelompok. Sears, dkk. (1995) mendefinisikan kohesivitas kelompok sebagai kekuatan positif maupun negatif yang nenyebabkan para anggota tetap tinggal di dalam kelompok. Kekompakan anggota merupakan karakteristik kelompok sebagai suatu kesatuan, dan merupakan hasil dari tingkat ikatan masing-masing anggota terhadap kelompoknya. Dalam kelompok yang kohesif, daya tarik antar pribadi yang terjadi pada antar anggota mrpk kekuatan positif. Bila anggota kelompok saling menyukai satu sama lain dan dieratkan dalam ikatan persahabatan, kohesivitas kelompok tersebut akan semakin tinggi. Kesesuaian tujuan pribadi anggota dengan tujua kelompok merupakan dasar motivasi bagi para individu untuk tetap tinggal dalam kelompok tersebut. Kohesivitas juga dipengaruhi oleh kekuatan negatif yang menyebabkan anggota kelompok tidak berani untuk meninggalkan kelompoknya tersebut. Anggota kelompok terkadang merasa akan memperoleh suatu kerugian yang akan ditanggungnya apabila ia meninggalkan kelompoknya (Sears, dkk., 1995).

Beberapa keadaan yang biasanya muncul sebagai akibat kelompok yang kohesif adalah meningkatnya kemauan anggota untuk menjadi anggota dalam segala bentuk aktivitas yang dilaksanakan kelompok. Kepuasan kerja biasanya juga merupakan hasil dari kelompok yang kohesif (Johnson and Johnson, 2000). Shaw (1981) melaporkan penelitian bahwa kelompok yang kohesif menghasilkan produktivitas dan kepuasan kerja yang lebih tinggi dibandingkan dengan kelompok yang tidak kohesif. Hal serupa juga dilaporkan oleh Dion (1973) bahwa di dalam kelompok yang kohesif komunikasi dapat lebih lancar, kooperatif, dan dimungkinkan adanya koreksi dan masukan yang positif.

Johnson and Johnson (2000) mendefinisikan kohesivitas kelompok sebagai daya saling ketertarikan antar anggota kelompok yang menyebabkan anggota- anggota kelompok tersebut berkeinginan untuk tetap tinggal dalam kelompok tersebut dan juga daya tarik antar individu dengan kelompok atau organisasinya. Kelompok yang memiliki kohesivitas tinggi bercirikan adanya keinginan untuk menetapkan tujuan kelompok dan keinginan untuk menapai tujuannya dengan baik. Keinginan untuk saling mempengaruhi sesama anggota juga tinggi. Komitmen terhadap tujuan kelompok dan keinginan untuk menyelesaikan tugas dengan sebaik-baiknya juga sangat tinggi. Hal lainnya yang merupakan dampak dari kohesivitas kelompok ialah rendahnya tingkat kehadiran dalam kegiatan-kegiatan kelompok (absenteeism) dan keinginan untuk keluar kelompok (turnover). Tanggung jawab pribadi terhadap kelompok juga akan meningkat. Selain itu keinginan untuk mengambil dan mengerjakan tugas kelompok yang berat, motivasi dan keajegan usaha untuk menyelesaikan tugas sebaik-baiknya. Keinginan untuk memikul segala kesukaran yang dihadapi kelompok, keinginan untuk melakukan pembelaan terhadap kritik dan ancaman eksternal, komitmen terhadap kesuksesan kerja sama anggota kelompok dan keinginan untuk mendengarkan dan mengikuti saran atau pendapat sesama anggota meningkat. Selanjutnya untuk perumusan konsep kohesivitas kelompok yang akan digunakan dalam penelitian ini, penulis mengklasifikasikan perilaku-perilaku tersebut di atas menjadi beberapa dimensi seperti yang dinyatakan oleh Johnson and Johnson (2000) bahwa kohesivitas merupakan kekuatan atau dorongan untuk tetap menetap dan memelihara keanggotannya dalam kelompok atau organisasi tertentu. Kekuatan tersebut meliputi daya tarik antar anggota dalam kelompok dan juga ketertarikan individu terhadap kelompok.

\section{Metode Penelitian}

Dalam penelitian ini terdapat tiga variabel bebas (independent) yaitu persepsi terhadap gaya kepemimpin transformasional, gaya 
kepemimpin transaksional, dan kohesivitas partai : komitmen afeksi, komitmen menerus, dan komitmen normatif; dan dua variabel sertaan lamanya menjadi ang kader partai dan usia kader.

Metode penelitian ini menggunakan analisis kuantitaif melalui analisis statistiknya. Penelitian ini menggunakan teknik analisis regresi berganda untuk melihat hubungan antara beberapa variabel bebas penelitian ini dengan variabel tergantung. Alat bantu analisis regresi berganda ini akan menggunakan paket SPS-2000 edisi Sutrisno Hadi.

Subjek penelitian ini adalah 120 anggota kader Partai Demokrasi Indonesia Perjuangan Ranting Banguntapan Kabupaten Bantul yang terdaftar sebagai anggota kader. Subjek tersebut dikenakan skala penelitian gaya kepemimpin transformasional dan transaksional yang disusun oleh Bass dan Avolio (1990), skala kohesivitas dalam kelompok berdasarkan konsep dari Johnson and Johnson (2000) serta skala komitmen organisasi dari Meyer dan Allen (1990).

\section{Hasil Penelitian}

Melaui analisis regresi berganda terhadap komitmen afeksi diperoleh koefisien korelasi $R_{y-}(1,2,3,4,5)$ sebesar $0,728, F$ sebesar 25,684 dan $p<0,01$. artinya bahwa terdapat hubungan yang positif dan sangat signifikan antara gaya kepemimpinan transformasional, gaya kepemimpin transaksional, kohesivitas partai, usia dan lama menjadi kader dengan komitmen afeksi terhadap partai. Dengan demikian hipotesis yang menyatakan bahwa gaya kepemimpinan transformasional, gaya kepemimpin transaksional, kohesivitas kelompok dalam partai dapat diterima.

Sementara itu sumbangan efektif usia, lama menjadi kader, gaya kepemimpin transformasional, gaya kepemimpin transaksional, kohesivitas partai adalah sebesar $52,975 \%$. Kepemimpinan transaksional memiliki sumbangan efektif terbesar $30,938 \%$ kemudian secara berturut-turut kohesivitas partai sebesar $15,568 \%$, kepemimpinan transformasional sebesar $4,212 \%$, lama menjadi kader sebesar $2,198 \%$ dan usia sebesar $0,058 \%$. Namun apabila kita mengacu kepada matriks interkorelasi akan nampak bahwa usia tidak berhubungan dengan komitmen afeksi partai.

Melalui analisis regrsi berganda terhadap komitmen menerus diperoleh koefisien korelasi $\mathrm{R}-\mathrm{-}_{\mathrm{y}}(1,2,3,4,5)$ sebesar $0,394, \mathrm{~F}$ sebesar 4,182 dan $p<0,05$. Artinya bahwa terdapat hubungan yang positif dan signifikan antara gaya kepemimpin transformasional, gaya kepemimpin transaksional, kohesivitas partai, usia dan lamanya menjadi kader dengan komitmen menerus terhadap partai. Dengan demikian hipotesis yang menyatakan bahwa gaya kepemimpinan transformasional, gaya kepemimpin transaksional, kohesivitas kelompok dalam partai, usia dan lamannya menjadi kader berhubungan positif dengan komitmen menerus terhadap partai dapat diterima. Besarnya sumbangan efekif usia, lamanya menjadi kader, gaya kepemimpin transformasional, gaya kepemimpin transaksional, dan kohesivitas kelompok dalam partai terhadap komitmen menerus adalah sebesar $15,500 \%$. Kepemimpinan transormasional memiliki sumbangan efektif terbesar yaitu $4,239 \%$ kemudian secara berturut-turut kohesivitas partai sebesar $4,026 \%$, kepemimpin transaksional sebesar $3,618 \%$, lama menjadi kader sebesar $2,152 \%$ dan usia sebesar $1,465 \%$. Namun apabila kita mengacu kepada matriks interkorelasi akan nampak bahwa usia tidak berhubungan dengan komitmen menerus partai.

Melalui analisis regresi berganda terhadap komitmen normatif diperoleh koefisien korelasi $R_{y}(1,2,3,4,5)$ sebesar $0,732, F$ sebesar 26,385 dan $p<0,010$. Artinya bahwa terdapat hubungan yang positif dan sangat signifikan antara gaya kepemimpin transformasional, gaya kepemimpin transaksional, kohesivitas kelompok dalam partai, usia dan lamanya menjadi dengan komitmen normatif 
terhadap partai. Dengan demkian hipotesis yang menyatakan bahwa gaya kepemimpin transformasional, gaya kepemimpin transaksional, kohesivitas partai, usia dan lamanya menjadi kader berhubungan positif dengan komitmen normatif partai dapat diterima. Besarnya sumbangan-sumbangan efektif usia, lamanya menjadi kader, gaya kepemimpin transformasional, gaya kepemimpin transaksional, dan kohesivitas kelompok dalam partai adalah sebesar $53,644 \%$. Kohesivitas partai memiliki sumbangan efektif terbesar yaitu $43,356 \%$ kemudian secara berturut-turut kepemimpinan transormasional sebesar $4,034 \%$, lama menjai kader $3,826 \%$, usia $1,919 \%$ dan kepemimpinan transaksional sebesar $0,509 \%$. Namun apabila kita mengacu pada matriks interkorelasi nampak bahwa usia tidak ber-hubungan dengan komitmen menerus partai.

\section{Pembahasan}

Secara umum dapat diketahui dari matriks interkorelasi hasil analisis regresi berganda bahwa usia berhbungan negatif terhadap komitmen model tiga komponen : komitmen afeksi, komitmen menerus dan komitmen normatif. Hal ini mnunjukkan bahwa semakin meningkat usia kader tidak diikuti oleh semakin meningkatnya komitmen terhadap partai. Meningkatnya usia tidak selalu diikuti secara positif oleh komitmen terhadap partai. Purwanto (2000) juga menemukan hal yang sama bahwa bawahan yang berusia tua dan muda tidak berkorelasi positif dengan komitmen partai. Hal tersebut dimungkinkan bahwa ketika masuk ke dalam partai dan kemudian diangkat menjadi anggota kader partai mereka telah memiliki tujuan dan harapan yang mantap.

Faktor kepemimpinan transormasional dan transaksional juga ternyata memberikan kontribusi bagi komitmen terhadap partai baik komitmen afeksi, komitmen menerus dan komitmen normatif. Temuan ini mendukung pendapat para ahli bahwa praktek gaya kepemimpin transformasional dan transaksional dapat menumbuhkan komitmen bawahan. Kebutuhan yang lebih rendah anggota seperti kebutuhan fisik, rasa aman, dan afiliasi dipenuhi oleh gaya kepemimpin transaksional (Kuhnert dan Lewis, 1987). Sementara itu kebutuhan yang lebih tinggi seperti harga diri dan aktualisasi diri dapat dipenuhi oleh gaya kepemimpin transformasional.

Seperti telah dipaparkan dalam pengantar, bahwa gaya kepemimpinan otokratik akan membawa konsekuensi tingginya tingkat turnover anggota dalam organisasi. Kepemimpinan otoriter biasanya mempertahankan wewenangnya dengan cara memerintah dan memberitahu pengikutnya apa yang harus dikerjakan tanpa melakukan konsultasi terlebih dahulu (DuBrin, dkk., 1996). Pada organisasi modern, kepemimpinan otoriter biasanya tidak akan bertahan lama karena mengundang ketidakpuasan anggota organisasi tersebut (Daft, 1999). Sebaliknya gaya kepemimpin transformasional memandang bawahan sebagai suatu kekuatan yang harus dikembangkan ke arah yang lebih baik sesuai dengan perubahan lingkungan melalui cara memotivasi bawahan, memberikan perhatian secara pribadi lepas pribadi dan lain sebagainya. Kepemimpinan transormasional juga meliputi nilai-nilai moral, akan tetapi nilai-nilai tersebut disesuaikan dengan proses pertukaran seperti kejujuran, keadilan, tanggung jawab. Bagi Burns (1978) kepemimpinan adalah sebuah proses, bukan sebuah serangkaian tindakan yang diskrit. Masih menurut Burns transforming leadership dapat dipandang pada dua level pengaruh, yaitu pengaruh level mikro yang terjadi antar individu dan proses pengaruh level makro yang ditujukan untuk menggerakkan kekuatan bagi perubahan sistem sosial dan reformasi institusi. Dalam analisis makro, kepemimpinan transormasional meliputi kegiatan seperti membentuk, mempertajam, dan mengekspresikan motivasi, serta memediasi konflik 
yang muncul. Konflik diantara faksi memang membuat kehidupan pemimpin menjadi sukar, namun pada saat yang bersamaan konflik dapat menjadi alat untuk memobilisir energi untuk mencapai tujuan-tujuan ideologis bersama. Adanya konflik yang mampu dimediasikan dengan baik oleh pemimpin akan membuat anggota merasa kerasan karena konflik yang ada ditransformasikan ke hal yang konstruktif. Sementara itu gaya kepemimpin transaksional juga memerankan peranan yang penting dalam menumbuhkan komitmen bawahan terhadap organisasinya. Pemimpin yang transaksional mengenali keinginan dan kebutuhan yang spesifik dari bawahannya dan kemudian menyediakan pemenuhan kebutuhannya sebagai pertukaran yang sesuai dengan pemenuhan tugas yang sesuai nilanya dengan imbalan yang diinginkan bawahannya tersebut. Dengan memeunhi kebutuhan dasar bawahan maka moral dan produktivitas bawahan mengarahkan komitmen bawahan untuk selalu mengikuti aturan yang ada maka pemimpin transaksional cenderung mempertahankan stabilitas daripada mempromosikan perubahan.

Komitmen terhadap partai juga dipengaruhi oleh kohesivitas kelompok dalam partai. Faktor utama kohesivitas menurut Johnson and Johnson (2000) ialah ketertarikan terhadap organisasi atau kelompok yang dalam hal ini ialah partai politik. Buchanan dalam Forsyth (1983), menyatakan bahwa ketika individu, semenjak awalnya, telah tertarik dengan tujuan dan nilai-nilai organisasi yang akan dimasukinya maka kelekatan afeksi terhadap organisasi tersebut bukanlah hal yang tidak mungkin. Dimensi kohesivitas ketertarikan terhadap sesama anggota menjelaskan bahwa hubungan tersebut tidak hanya bersifat fisik, namun juga secara mental dan emosional. Melalui interaksi sosial seperti itu masing-masing anggota organisasi akan mengetahui penghargaan dan pengakuan dari sesama anggota dan organisasi mengenai keberadaan mereka. Bila hubungan sosial individu dapat terpenuhi melalui interaksi dengan sesama anggota dalam organisasi maka individu akan mempertahankan keberadaannya dalam organisasi tersebut (Brigham, dkk., 1991). Hal ini berarti ketertarikan terhadap sesama anggota dalam partai mempengaruhi komitmen kader terhadap partainya. Partai yang memiliki kohesivitas yang tinggi akan dipersepsi sebagai suatu modal atau aset dari partai yang belum tentu dimiliki oleh partai lainnya sehingga dapat menumbuhkan komitmen normatif anggota partai. Anggota kader yang melihat dan merasakan betapa tingginya kohesivitas partai juga menilai hal tersebut sebagai nilai moral mengenai hubungan sosial yang baik. Penilaia seperti itu akan meyakinkan bahwa nilai moral yang juga harus tetap dipelihara sehingga komitmen normatif partai juga akan tetap terjaga.

\section{Kesimpulan}

Penelitian ini menunjukkan bahwa gaya kepemimpinan transformasional, gaya kepemimpin transaksional, kohesivitas kelompok dalam partai, usia dan lamannya menjadi kader berhubungan positif dengan komitmen menerus terhadap partai dapat diterima.

\section{Saran}

Melalui hasil penelitian ini, peneliti menyarankan beberapa hal :

1. Bagi para pelaksana eksekutif partai di lingkungan kerja organisasi PDI Perjuangan, dengan ditemukannya bukti bahwa terdapat hubungan positif antara gaya kepemimpin transformasional, gaya kepemimpin transaksional, dan kohesivitas kelompok dalam partai terhadap komitmen organisasi : komitmen afeksi, komitmen menerus, dan komitmen normatif maka perlu dpertimbangkan untuk tetap memlihara kekompakan sesama anggota partai 
(kohesivitas). Hasil penelitian tersebut menunjukkan bahwa citra PDI Perjuangan sebagai partai rakyat atau wong cilik diperkuat dengan ditemukannya kohesivitas partai yang cukup tinggi. Praktek kepemimpinan transformasional dan transaksional perlu dipertimbangkan untuk diterapkan dalam tugas keseharian partai mengingat keduanya berhubungan positif dengan komitmen anggota kader terhadap partai politik.

2. Bagi para peneliti selanjutnya diharapkan untuk memasukkan variabel lain di luar variabel yang ada pada penelitian in sehingga akan lebih jelas perbedaan anteseden pada komitmen afeksi, menerus dan normatif. Apabila dimungkinkan, penelitian mengenai komitmen organisasi dilaksanakan pada organisasi yang bersifat non-profil sehingga dapat diketahui perbedaan tipe komitmen organisasi pada organisasi profit dan non profit.

\section{Daftar Pustaka}

Anita. 2002. Kader PDI Perjuangan Rakyat. Koran Harian BERNAS. Edisi Senin 26 Agustus 2002. No. 279. halaman 1.

Bass, B.M., 1985. Leadership and Performance Beyond Expection. New York : The Free Press.

Bass, B.M., and Avolio, B.J., 1990. The Implications of Transactional and Tranformational Leadership for Individual, Team and Organizational Development. Greenwich: JAI Press.

Daft, R.L. 1999. Leadership : Theory and Practice. Texas: The Dryden Press, Harcourt Brace \& Company.

Dion, K., 1973. Cohesiveness as A Determinant of In Group Out Group Bias. Journal of Personality and Social Psychology, 28, (1), 163-171.

DuBrin, A.J., Ireland, R.D., and Williams, J.C., 1996. Management and Orga- nization. Cincinnati, Ohio : SouthWestern Publishing Co.

Burns, J.M. 1978. Leadership. New York : Harper and Row

Forsyth, D.R. 1983. An Introduction to Group Dynamics. California : Brook/ Cole Publishing Company.

Greenberg, J. and Baron, R.A., J. 1997. Behaviour in Organizations. Understanding and Managing the Human Side of Work. New Jersey : PrenticeHall, Inc.

Hornby, A.S. 1987. Oxford aAdvanced Learner's Dictionary of Current English, Oxford : Oxford University Press.

Ismail, M. 26 Agustus 2002. Partai Tandingan Menjadi Ancaman Bagi PDIP. Download 30 Agustus. 07:48 pm. @tempointeraktif.com

Johnson, D.W. and Johnson, F.P. 2000. Joining Together: Group Theory and Group Skills. Boston : Allyn \& Bacon.

Keashly, L. 1997. Conflict and Conflict Management. Dalam Sadava S.W. dan McCreary, D.R. Applied Social Psychology. New Jersey, Upper Saddle River: Prentice Hall.

Kuhnert, K.W. and Lewis, P. Transactional and Transormational Leadership : A Constructive/Development Analysis. Academy of Management Review, 12, (4), 648-657.

Meyer, J.P. and Allen, N.J. 1980. The Measurement and Antecedents of Affective, Continuance and Normative Commitment to the Organization. Journal of Occupational Psychology. 63, (1), 1-18.

Purwanto, B., 2000. Hubungan antara Kepemimpinan Transformasional dan Kepemimpinan Traksaksional dengan Komitmen Organisasi. Tesis. (tidak diterbitkan)

Sears, D.O., Freedman, J.L., dan Peplau, L.A. 1999. Psikologi Sosial. (Alih Bahasa : Adryanto, M. dan Soekrisno, 
S.). Jakarta : Penerbit Erlangga.

Shaw. M.E. 1981. Group Dynmics. The Psychology of Small Group Behavior. New York: McGraw-Hill Company.
Steers, R.M., Porter, L.W., dan Bigley, G.A. 1996. Motivation and Leadership at Work. New York: The McGraw-Hill Companies Inc.

2ocoscoscoscos 